\title{
Changes in the Physicochemical Quality Characteristics of Cabbage Kimchi with respect to Storage Conditions
}

\author{
Su-Yeon You, Ji-Su Yang, Sung Hyun Kim, and In Min Hwang \\ World Institute of Kimchi, Gwangju, Republic of Korea \\ Correspondence should be addressed to In Min Hwang; imhwang@wikim.re.kr
}

Received 14 September 2016; Revised 7 November 2016; Accepted 10 November 2016; Published 15 January 2017

Academic Editor: Jesús Lozano

Copyright (C) 2017 Su-Yeon You et al. This is an open access article distributed under the Creative Commons Attribution License, which permits unrestricted use, distribution, and reproduction in any medium, provided the original work is properly cited.

\begin{abstract}
In this study, the changes in $\mathrm{pH}$, organic acid content, acidity, and salinity of kimchi prepared at 0 days, stored 1-8 weeks at 4 and $10^{\circ} \mathrm{C}$, and stored at room temperature for two days were analyzed. Organic acids content was analyzed by using analytical technique of high-performance liquid chromatography (HPLC). This method was also validated using quality assurance parameters of linearity, limits of detection and quantification (LOD and LOQ), precision, and spike recovery experiments. In the analysis of organic acids content $(\mathrm{mg} / \mathrm{kg})$, it was found that the kimchi stored for 1-8 weeks at 4 and $10^{\circ} \mathrm{C}$ showed gradual increase in the organic acids content during storage period. The order of organic acids was lactic acid $>$ acetic acid $>$ citric acid $>$ malic acid $>$ succinic acid $>$ oxalic acid $>$ fumaric acid. The $\mathrm{pH}$ values of kimchi stored at $4^{\circ} \mathrm{C}, 10^{\circ} \mathrm{C}$, and $25^{\circ} \mathrm{C}$ were $4.1,3.6-3.7$, and 4.1 , respectively.
\end{abstract}

\section{Introduction}

Kimchi is a traditional fermented food item and side dish with a unique flavor in Korea consumed for over a long time period. Now, it has been consumed as a health food in different countries. The main ingredients of kimchi are cabbage and radish. However, before fermentation various spices such as chili powder, ginger, green onion, garlic, and salted seafood are also added to it. The organic acids and free amino acids generated during fermentation render kimchi its unique flavor. Chinese cabbage kimchi (Baechu kimchi) has unique flavors which vary with the ingredients as well as ripening and distribution [1]. In the past, it had been in houses only. However, due to the changes in the diets of modern society following socioeconomic development, currently, it is produced by companies on a large scale [2]. Segmentation of the kimchi market owing to expansion of the commercial kimchi market and diversification of kimchi preference by consumers has resulted in a growing demand for kimchi of varied ripeness [3].

During the fermentation of kimchi, the content of organic acids increases and that of sugar decreases. Concerning the $\mathrm{pH}$, it decreases with fermentation which directly and indirectly affects the sensory characteristics of kimchi [4].
Previous studies on the fermentation characteristics of kimchi indicated that the flavor of kimchi is significantly affected by fermentation, ripening and distribution. Lee and Chun [5] reported that its shelf life when fermented at $4^{\circ} \mathrm{C}$ and $28^{\circ} \mathrm{C}$ is 30 and 3 days, respectively. Furthermore, another study reported that kimchi stored at $17^{\circ} \mathrm{C}$ for 4 days and that stored at $4^{\circ} \mathrm{C}$ for 48 days have similar quality characteristics. Also, changes in $\mathrm{pH}$, acidity, and organic acid content were reported by the researchers $[5,6]$.

Organic acids are produced by the growth of lactobacillus during fermentation and ripening of kimchi by converting the fermentable sugar contained in vegetables to lactic acid or other organic acids [2]. Thus, ripening and acidification of kimchi directly affect the organic acid production, and sour and savory flavors harmonize at an optimum fermentation time [7]. There are several studies on changes of quality during the fermentation and the factors affecting the flavor and quality of kimchi [8]. The nonvolatile organic acids in kimchi with respect to ripening temperature [9], changes of organic acids and volatile flavor components of kimchi with respect to types of ingredients [10], changes of biological and chemical properties of over-ripened kimchi [11], and effects of the combination of fermentation temperature and time on 
the quality characteristics of cabbage kimchi [12] have been also previously investigated.

Because of the varied ingredients and fermentation environment, kimchi varies significantly; therefore, it is difficult to analyze its characteristics. There are very few studies on changes of acidity or organic acids content with respect to specific conditions during kimchi fermentation. Low-temperature/refrigeration temperature fermentation and storage is widely employed for kimchi ripening. The studies conducted thus far indicate that total acidity, which is an indirect quality index, is highly affected by ripening temperature which in turn significantly affects the fermentation speed of kimchi $[8,13]$. In addition, fermentation patterns are more strongly associated with temperature than salinity as the bacteria involved vary with the fermentation temperature, resulting in the changes in kimchi flavor [12]. The time required to reach $\mathrm{pH} 4.2$, which is the $\mathrm{pH}$ for the optimal flavor of kimchi, is 10 days at $4^{\circ} \mathrm{C}, 2.4$ days at $15^{\circ} \mathrm{C}, 1$ day at $25^{\circ} \mathrm{C}$, and $19 \mathrm{~h}$ at $35^{\circ} \mathrm{C}[8]$.

The current study was aimed at analyzing the changes in quality attributes such as $\mathrm{pH}$, organic acids content, acidity, and salinity of the kimchi stored at different temperatures and time, which contribute to kimchi flavour.

\section{Materials and Methods}

2.1. Samples. In this study, cabbage kimchi samples used were from summer cabbage grown in Taebaek, Korea, in 2015. All the raw materials used for preparing samples were purchased from Western Agricultural Market in Gwangju Metropolitan City, Korea. The minor ingredients such as chili powder and fermented anchovy sauce required for making kimchi were purchased from market.

2.2. Kimchi Production and Storage Conditions. Cabbage and additional minor ingredients were preprocessed on the day of purchase so that kimchi could be made the following day. Cabbages were sliced in half after the removal of nonedible parts. Subsequently, the cabbage pieces were salted using the salt water soaking method at room temperature $\left(25^{\circ} \mathrm{C}\right)$ for $12 \mathrm{~h}$ in salt water with a salinity of $10 \%$ [4]. For homogeneous salting, water baskets were used to soak all cabbages and after 2-3 h the cabbage in the upper and lower positions were switched. After $18 \mathrm{~h}$, salted cabbages were washed 3 times and water was drained for $2 \mathrm{~h}$. Then, a prepared seasoning consisting of radish, green onion, garlic, ginger, fermented anchovy sauce, chili powder, and glutinous rice paste was added to make kimchi. The prepared kimchi sample was taken at 0 days and also divided into batches to be stored and fermented for $1-8$ weeks at 4,10 , and $25^{\circ} \mathrm{C}$ which were then fermented at each temperature. The quality characteristics of kimchi were analyzed at each week from 1-8 weeks at $4^{\circ} \mathrm{C}$ and $10^{\circ} \mathrm{C}$, and the kimchi stored at room temperature was rapidly ripened for 2 days before its use in the experiment.

2.3. Measurement of $\mathrm{pH}$ and Acidity. Each $500 \mathrm{~g}$ of kimchi stored under each condition was homogenized in a blender (HR1372, 700 W; Philips, Amsterdam, Netherlands) for measuring the $\mathrm{pH}$ and acidity of each sample. The solid contents
TABLE 1: HPLC analysis operating conditions and parameters for determination of organic acids.

\begin{tabular}{lc}
\hline HPLC & $\begin{array}{c}\text { Agilent } 1260 \text { Infinity } / \mathrm{G} 4212 \mathrm{~B} 1260 \mathrm{DAD} \\
\text { Aminex } \mathrm{HP} \times 87 \mathrm{H} \text { column }(7.8 \mathrm{~mm} \times 300 \mathrm{~mm}, \\
\text { Column }\end{array}$ \\
$\begin{array}{lc}\text { Mobile phase } \\
\text { Detector }\end{array}$ & $0.008 \mathrm{~N} \mathrm{H}_{2} \mathrm{SO}_{4}$ \\
Injection volume & $\mathrm{DAD}, 210 \mathrm{~nm}$ \\
Flow rate & $10 \mu \mathrm{L}$ \\
\hline
\end{tabular}

were filtered through sterilized gauze and the filtrate was used for subsequent measurements. The $\mathrm{pH}$ and acidity were both measured using a pH meter (TitroLine 5000; SI Analytics, Mainz Germany). The $\mathrm{pH}$ was measured by immersing a $\mathrm{pH}$ electrode of the $\mathrm{pH}$ meter in kimchi liquid. For measuring acidity by the Association of Official Analytical Chemists (AOAC) method [14], the amount of $0.1 \mathrm{~N} \mathrm{NaOH}$ required to neutralize $10 \mathrm{~mL}$ of kimchi liquid to $\mathrm{pH} 8.3$ was used. It was converted to lactic acid content (\%) and recorded as the titratable acidity. Each experiment was conducted in triplicate for obtaining mean and standard deviation.

2.4. Measurement of Salinity. For measuring salinity, $1 \mathrm{~g}$ of each homogenized kimchi sample was added to a $100 \mathrm{~mL}$ flask and adjusted to a constant volume with distilled water. Then, $100 \mathrm{~mL}$ well-mixed sample solution was filtered in a $100 \mathrm{~mL}$ Erlenmeyer flask and the filtrate was used for measurements. Using the Mohr method [15] to measure salinity, $1 \mathrm{~mL}$ of $2 \%$ potassium chromate was added to $10 \mathrm{~mL}$ of the filtrate and $0.02 \mathrm{~N} \mathrm{AgNO}_{3}$ was used for titration. The amount of $0.02 \mathrm{~N} \mathrm{AgNO}_{3}$ used to change the color to red was observed.

2.5. Organic Acid Content Analysis. Each $500 \mathrm{~g}$ of kimchi stored under each condition was homogenized in a blender for measuring the organic acid content of the samples. Then, $12.5 \mathrm{~mL}$ of distilled water was added to $2 \mathrm{~g}$ of sample. The organic acids were extracted for $30 \mathrm{~min}$ using a sonicator (Power Sonic 520; Hwashin Tech Co., Daegu, Korea). After extraction, the sample extract adjusted to $25 \mathrm{~mL}$ was filtered using a filter paper. This filtrate was then filtered using a syringe filter (RC, $0.2 \mu \mathrm{m}, 25 \mathrm{~mm}$ ) and used for highperformance liquid chromatography (1260 Infinity/G4212B; Agilent Co., Santa Clara, CA, USA) analysis. Oxalic acid, citric acid, tartaric acid, malic acid, succinic acid, lactic acid, fumaric acid, and acetic acid (Sigma, St. Louis, Missouri, USA), were used as standards for organic acids analysis. The standards and the samples were analyzed by HPLC using the conditions set by [16] which are given in Table 1 . The organic acids detected in the kimchi samples were identified by comparing the retention times with those of the standard organic acids. Then, the organic acids in each sample were quantitatively analyzed using a calibration curve derived from the peak areas of the standard organic acids.

2.6. Quality Assurance. The analytical method for the determination of the organic acids in kimchi was validated by 
TABLE 2: Analytical parameters for HPLC analysis of organic acids.

\begin{tabular}{|c|c|c|c|c|c|}
\hline Organic acid & Correlation coefficient $\left(R^{2}\right)$ & $\mathrm{LOD}^{1}(\mathrm{mg} / \mathrm{kg})$ & $\mathrm{LOQ}^{2}(\mathrm{mg} / \mathrm{kg})$ & Recovery $^{3}(\%)$ & $\mathrm{CV}^{4}(\%)$ \\
\hline Oxalic acid & 0.99986 & 4.447 & 13.475 & 97.55 & 0.53 \\
\hline Citric acid & 0.99978 & 1.136 & 3.442 & 91.60 & 0.54 \\
\hline Tartaric acid & 0.99985 & 1.759 & 5.329 & 100.99 & 0.37 \\
\hline Malic acid & 0.99972 & 1.683 & 5.101 & 107.21 & 1.29 \\
\hline Succinic acid & 0.99955 & 1.321 & 4.003 & 109.81 & 1.26 \\
\hline Lactic acid & 0.99958 & 1.503 & 4.555 & 93.35 & 0.81 \\
\hline Fumaric acid & 0.99915 & 1.309 & 3.967 & 90.12 & 0.72 \\
\hline Acetic acid & 0.99880 & 0.806 & 2.442 & 97.55 & 1.99 \\
\hline
\end{tabular}

${ }^{1}$ Limit of detection.

${ }^{2}$ Limit of quantification.

${ }^{3}$ Recovery of citric acid, malic acid, succinic acid, lactic acid, and acetic acid spiked at 1,000 ppm, oxalic acid spiked at $200 \mathrm{ppm}$, tartaric acid spiked at $500 \mathrm{ppm}$, and fumaric acid spiked at $5 \mathrm{ppm}$.

${ }^{4}$ Coefficient of variation.

evaluating several quality control parameters such as linearity, limits of detection (LOD) and limits of quantification (LOQ), precision, and accuracy (spike recovery\%). Linearity in terms of correlation coefficient $\left(R^{2}\right)$ values was determined from the calibration curves $[17,18]$. The LOD and LOQ were calculated as three and ten times of the standard deviations of the blank divided by the slope of the analytical curve, respectively [19]. The precision was determined by evaluating the coefficient of variation (CV\%) using the relative standard deviation of ten repeated determinations of one sample [20]. The analytical quality control was verified by the recovery experiments spiking at selected concentration in the samples.

2.7. Statistical Analysis. Each experiment was repeated three or more times and presented as mean \pm standard deviation. To test the significance of the results, the SPSS Version 8.2 software (SPSS Institute Inc., Cary, NC, USA) was used. Duncan's multiple range test was conducted at $p<0.05$. The difference in the organic acid content of kimchi with respect to storage temperature was evaluated by linear discriminant analysis (LDA). LDA is a nonparametric test that assumes that various classes of similar objects are described by multivariate normal distributions with the same covariance. LDA was performed using the XLSTAT 2015 program (Addinsoft, Paris, France) [21].

\section{Results and Discussion}

3.1. Validation of Analytical Method. In validation of the HPLC analytical method, the values of LOD were in the range of $0.806-4.447(\mathrm{mg} / \mathrm{kg})$ and the LOQ values ranged from 2.442 to $13.475(\mathrm{mg} / \mathrm{kg}$ ) (Table 2). The recovery (\%) was found to be in the range of $90.12-109.81 \%$. The CV\% values obtained were all less than 3\% (0.37-1.99\%). Thus, the results obtained for the quality assurance parameters indicated that the applied analytical method is fully validated and fulfils the criteria required by AOAC.

3.2. Changes of $p H$ during Storage. During the fermentation of kimchi, major components contained in Chinese cabbage and minor ingredients (salted seafood, chili powder, green onion, garlic, and ginger) are degraded or synthesized by microorganisms using various enzymes. The degradation of carbohydrates, a major component of Chinese cabbage, results in the formation of numerous organic acids which gives unique flavor to kimchi $[5,22,23]$. Thus, the $\mathrm{pH}$, total acidity and organic acid of kimchi are important quality indices for determining the quality and storage level of kimchi. The $\mathrm{pH}$ changes in kimchi at 0 days and stored at 4 and $10^{\circ} \mathrm{C}$ for 8 weeks are summarized in Table 3. From the results, it can be noticed that the kimchi stored at $25^{\circ} \mathrm{C}$ for 2 days exhibited a $\mathrm{pH}$ of 4.1 and that at 0 days it exhibited a $\mathrm{pH}$ of 5.3. However, the one stored at $4^{\circ} \mathrm{C}$ showed a $\mathrm{pH}$ change ranged from 5.3 to 5.8 during 1-3 weeks which did not change considerably during early storage. However, as weeks passed, the $\mathrm{pH}$ gradually decreased to 4.1 . The $\mathrm{pH}$ of kimchi stored at $10^{\circ} \mathrm{C}$ for 8 weeks exhibited an early rapid decrease from 5.8 at 0 days to 4.7 at 1 week. It gradually decreased until 6 weeks until it remained constant at 3.6-3.7. The $\mathrm{pH}$ values of the kimchi stored at $25^{\circ} \mathrm{C}$ were 5.3 at 0 day and $4.1 \pm 0.1$ at 2 days. In general, the $\mathrm{pH}$ changes in kimchi at each temperature during fermentation exhibit a sigmoid curve: a slow decrease at the initial fermentation until it reaches 5.4 as fermentation progresses, rapid decrease to $4.2-4.4$ at intermediate fermentation stage (the optimal fermentation stage), and a decrease to 4.0 at the final fermentation stage [8]. Such sigmoid curve is observed for the growth of living organisms which in case of kimchi is attributed to bacteria. In this study, the initial fermentation stage for kimchi stored at $4^{\circ} \mathrm{C}$ was observed until three weeks and the intermediate fermentation stage was observed over three weeks until the $\mathrm{pH}$ reached 4.1. However, kimchi stored at $10^{\circ} \mathrm{C}$ exhibited a very short initial fermentation stage and a rapid $\mathrm{pH}$ decrease in the intermediate fermentation stage. From 6 to 8 weeks when $\mathrm{pH}$ was 3.7, the final fermentation stage was observed with no changes in $\mathrm{pH}$ values. The kimchi produced in summer and stored at 4 and $10^{\circ} \mathrm{C}$ exhibited different trends in $\mathrm{pH}$ with storage over 8 weeks. The results suggest that low-temperature storage at $4^{\circ} \mathrm{C}$ allows a slower fermentation rate and permits long-term fermentation, whereas kimchi stored at $10^{\circ} \mathrm{C}$ exhibits high initial fermentation, which slows down once a certain fermentation level is reached. It further 
TABLE 3: pH, acidity, and salinity of kimchi samples stored at 4 and $10^{\circ} \mathrm{C}^{1,2}$.

\begin{tabular}{|c|c|c|c|}
\hline Storage period & $\mathrm{pH}$ & Acidity (\%) & Salinity $(\%)$ \\
\hline 0 days & $5.84 \pm 0.01^{\mathrm{c}}$ & $0.25 \pm 0.00^{\mathrm{p}}$ & $2.03 \pm 0.00^{\mathrm{i}}$ \\
\hline \multicolumn{4}{|c|}{ Storage period (weeks) and temperature $\left(4^{\circ} \mathrm{C}\right)$} \\
\hline 1 & $5.76 \pm 0.01^{\mathrm{a}}$ & $0.27 \pm 0.01^{\mathrm{q}}$ & $1.84 \pm 0.01^{\mathrm{k}}$ \\
\hline 2 & $5.52 \pm 0.01^{\mathrm{b}}$ & $0.36 \pm 0.00^{\circ}$ & $2.10 \pm 0.01^{\mathrm{h}}$ \\
\hline 3 & $5.31 \pm 0.01^{\mathrm{d}}$ & $0.38 \pm 0.01^{\mathrm{n}}$ & $2.28 \pm 0.01^{\mathrm{d}}$ \\
\hline 4 & $5.07 \pm 0.00^{\mathrm{e}}$ & $0.42 \pm 0.01^{\mathrm{m}}$ & $2.15 \pm 0.01^{\mathrm{g}}$ \\
\hline 5 & $4.90 \pm 0.01^{\mathrm{f}}$ & $0.43 \pm 0.01^{1}$ & $2.23 \pm 0.01^{\mathrm{f}}$ \\
\hline 6 & $4.74 \pm 0.00^{\mathrm{g}}$ & $0.53 \pm 0.01^{j}$ & $2.35 \pm 0.01^{\mathrm{b}}$ \\
\hline 7 & $4.27 \pm 0.00^{j}$ & $0.69 \pm 0.02^{\mathrm{h}}$ & $2.52 \pm 0.01^{\mathrm{a}}$ \\
\hline 8 & $4.12 \pm 0.00^{\mathrm{k}}$ & $0.79 \pm 0.01^{\mathrm{g}}$ & $2.22 \pm 0.02^{\mathrm{f}}$ \\
\hline \multicolumn{4}{|c|}{ Storage period (weeks) and temperature $\left(10^{\circ} \mathrm{C}\right)$} \\
\hline 1 & $4.68 \pm 0.01^{\mathrm{h}}$ & $0.51 \pm 0.01^{\mathrm{k}}$ & $2.15 \pm 0.02^{\mathrm{g}}$ \\
\hline 2 & $4.33 \pm 0.01^{\mathrm{i}}$ & $0.66 \pm 0.01^{\mathrm{i}}$ & $2.14 \pm 0.01^{\mathrm{g}}$ \\
\hline 3 & $3.96 \pm 0.01^{1}$ & $1.01 \pm 0.02^{\mathrm{f}}$ & $2.22 \pm 0.01^{\mathrm{f}}$ \\
\hline 4 & $3.85 \pm 0.04^{\mathrm{m}}$ & $1.22 \pm 0.02^{\mathrm{e}}$ & $2.32 \pm 0.01^{c}$ \\
\hline 5 & $3.76 \pm 0.01^{\mathrm{n}}$ & $1.26 \pm 0.02^{\mathrm{d}}$ & $1.99 \pm 0.00^{\mathrm{j}}$ \\
\hline 6 & $3.70 \pm 0.00^{\circ}$ & $1.51 \pm 0.02^{\mathrm{b}}$ & $1.81 \pm 0.02^{1}$ \\
\hline 7 & $3.64 \pm 0.00^{\mathrm{q}}$ & $1.48 \pm 0.00^{c}$ & $2.53 \pm 0.01^{\mathrm{a}}$ \\
\hline 8 & $3.68 \pm 0.01^{\mathrm{p}}$ & $1.57 \pm 0.01^{\mathrm{a}}$ & $2.25 \pm 0.01^{\mathrm{e}}$ \\
\hline \multicolumn{4}{|c|}{ Storage period (days) and temperature $\left(25^{\circ} \mathrm{C}\right)$} \\
\hline 2 & $4.1 \pm 0.1$ & $0.91 \pm 0.1$ & $2.22 \pm 0.1$ \\
\hline
\end{tabular}

${ }^{1}$ Each value is mean $\pm \mathrm{SD}(n=3)$.

${ }^{2}$ Means with the different superscript letters in the same column are significantly different $(p<0.05)$.

indicates that $\mathrm{pH}$ changes are more highly associated with temperature rather than salinity, implying that fermentation temperature largely affects the flavor of kimchi [24].

3.3. Changes of Acidity during Storage. The results of acidity changes in kimchi, stored at 4 and $10^{\circ} \mathrm{C}$ for 8 weeks, are shown in Table 3. The results showed that kimchi stored at $4^{\circ} \mathrm{C}$ showed no considerable acidity changes $(0.3-0.4 \%$ from 0 day to 5 weeks). In contrast, the acidity of kimchi stored at $10^{\circ} \mathrm{C}$ increased from the early storage stage showing $0.3-1.57 \%$ increase from 0 days to 8 weeks. The acidity of kimchi stored at $10^{\circ} \mathrm{C}$ exhibited the initial, intermediate, and final stages in the same manner as that observed for $\mathrm{pH}$ changes, whereas that stored at $4^{\circ} \mathrm{C}$ showed a gradual increase in acidity. As a result, the acidity of kimchi stored at $10^{\circ} \mathrm{C}$ was $1.57 \%$ at 8 weeks, which was two times that of kimchi stored at $4^{\circ} \mathrm{C}(0.79 \%)$. The acidity of kimchi of 25 storage temperature exhibited the acidity of $0.25 \%$ and $0.9 \%$ at 0 and 2 days, respectively. During the fermentation of kimchi, various organic acids are generated by the reproduction of microorganisms which lower the $\mathrm{pH}$ and increase the acidity of kimchi [8]. An increase of total acidity and a decrease of $\mathrm{pH}$ have been reported to be significantly affected by microorganisms, sugar content, salt concentration, and temperature. Generally, the $\mathrm{pH}$ decline is a gradual decrease compared with the increase of total acidity, which is assumed to be caused by the buffer reaction of proteins and amino acids in kimchi [25]. The acidity does not increase significantly because aerobic microorganisms unassociated with acid production are temporarily active during the early ripening of kimchi, lactobacillus remains inactive and also because of water being released from Chinese cabbage [26]. In our study, the acidity of kimchi stored at $4^{\circ} \mathrm{C}$ gradually increased from 5 weeks, whereas kimchi stored at $10^{\circ} \mathrm{C}$ increased rapidly from 0 days to 5 weeks. These changes in acidity are significantly affected by ripening temperature and saline concentration as lactobacillus start to grow after their inactive period. From the previous studies, it was found that it took 2 days to reach full ripening at a salinity of $3 \%$ and a storage temperature of $20^{\circ} \mathrm{C}, 1$ day at a salinity of $2.25 \%-3.50 \%$ and a storage temperature of $30^{\circ} \mathrm{C}$, and $2-4$ days at a salinity of $5 \%$ and a storage temperature of $30^{\circ} \mathrm{C}$ [27]. Considering that optimal fermentation occurs at an acidity and $\mathrm{pH}$ of $0.6 \%$ and 4.2 , respectively, in the current study, kimchi ripened for 7 weeks at a storage temperature of $4^{\circ} \mathrm{C}$ exhibited a $\mathrm{pH}$ of 4.3 and acidity of $0.7 \%$, whereas kimchi ripened for 2 weeks at a storage temperature of $10^{\circ} \mathrm{C}$ exhibited a $\mathrm{pH}$ of 4.3 and acidity of $0.7 \%$. These optimal fermentation times were determined to be the time of full ripening above these conditions.

3.4. Changes of Salinity during Storage. In this study, the kimchi prepared at 0 day and that stored at 4 and $10^{\circ} \mathrm{C}$ were analyzed for the salinity differences. From the results given in Table 3, the salt content ranged from $1.81 \%$ to $2.35 \%$, suggesting that the salinity of kimchi did not change considerably at each storage time and temperature. The salinity of 
TABLE 4: Organic acids content $(\mathrm{mg} / \mathrm{kg})$ in kimchi samples stored at 4 and $10^{\circ} \mathrm{C}^{1,2}$.

\begin{tabular}{|c|c|c|c|c|c|c|c|c|}
\hline $\begin{array}{l}\text { Storage } \\
\text { period }\end{array}$ & Oxalic acid & Citric acid & Tartaric acid & Malic acid & Succinic acid & Lactic acid & Fumaric acid & Acetic acid \\
\hline & $16.0 \pm 0.5$ & $1,362.3 \pm 84.0$ & ND & $1,546.6 \pm 13.0$ & ND & ND & $11.5 \pm 0.1$ & $273.4 \pm 9.8$ \\
\hline \multicolumn{9}{|c|}{ Storage period (weeks) and temperature $\left(4^{\circ} \mathrm{C}\right)$} \\
\hline 1 & $21.9 \pm 0.8^{\mathrm{e}}$ & $1,565.0 \pm 5.0^{\mathrm{a}}$ & ND & $1,183.8 \pm 14.6^{\mathrm{b}}$ & ND & $\mathrm{ND}^{\mathrm{g}}$ & $11.1 \pm 0.1^{\mathrm{a}}$ & $279.7 \pm 5.3^{\mathrm{h}}$ \\
\hline 2 & $29.3 \pm 0.7^{c}$ & $1,250.6 \pm 2.2^{\mathrm{b}}$ & ND & $1,469.8 \pm 32.6^{\mathrm{a}}$ & ND & $188.1 \pm 1.6^{\mathrm{f}}$ & $9.8 \pm 0.1^{\mathrm{b}}$ & $391.4 \pm 8.0^{\mathrm{g}}$ \\
\hline 3 & $33.0 \pm 1.1^{b}$ & $1,220.9 \pm 9.9^{b c}$ & ND & $906.5 \pm 4.4^{\mathrm{d}}$ & ND & $296.1 \pm 6.9^{\mathrm{e}}$ & $9.6 \pm 0.0^{c}$ & $460.5 \pm 9.4^{\mathrm{e}}$ \\
\hline 4 & $29.0 \pm 0.9^{c}$ & $1,129.7 \pm 10.6^{\mathrm{d}}$ & ND & $1,046.8 \pm 17.8^{\mathrm{c}}$ & ND & $292.8 \pm 4.9^{\mathrm{e}}$ & $8.0 \pm 0.0^{\mathrm{d}}$ & $437.9 \pm 9.4^{\mathrm{f}}$ \\
\hline 5 & $25.7 \pm 0.7^{\mathrm{d}}$ & $1,189.1 \pm 44.2^{\mathrm{c}}$ & ND & $770.8 \pm 10.6^{\mathrm{e}}$ & ND & $1,013.9 \pm 67.1^{\mathrm{d}}$ & $7.9 \pm 0.0^{\mathrm{d}}$ & $476.9 \pm 12.0^{\mathrm{d}}$ \\
\hline 6 & $36.6 \pm 1.7^{\mathrm{a}}$ & $1,069.2 \pm 11.5^{\mathrm{e}}$ & ND & $305.0 \pm 10.5^{\mathrm{f}}$ & ND & $2,005.1 \pm 12.4^{c}$ & $4.9 \pm 0.0^{\mathrm{g}}$ & $649.2 \pm 2.9^{c}$ \\
\hline 7 & $29.1 \pm 0.4^{\mathrm{c}}$ & $872.5 \pm 35.4^{\mathrm{f}}$ & ND & $\mathrm{ND}^{\mathrm{g}}$ & ND & $4,149.7 \pm 24.2^{\mathrm{b}}$ & $6.5 \pm 0.1^{\mathrm{e}}$ & $698.3 \pm 2.1^{\mathrm{b}}$ \\
\hline 8 & $31.5 \pm 0.9^{\mathrm{b}}$ & $751.7 \pm 1.9^{\mathrm{g}}$ & ND & $\mathrm{ND}^{\mathrm{g}}$ & ND & $5,194.9 \pm 32.5^{\mathrm{a}}$ & $5.7 \pm 0.0^{f}$ & $821.6 \pm 8.7^{\mathrm{a}}$ \\
\hline \multicolumn{9}{|c|}{ Storage period (weeks) and temperature $\left(10^{\circ} \mathrm{C}\right)$} \\
\hline 1 & $31.7 \pm 1.4^{\mathrm{c}}$ & $576.6 \pm 60.1^{\mathrm{a}}$ & ND & $434.3 \pm 15.6^{\mathrm{a}}$ & $\mathrm{ND}^{\mathrm{c}}$ & $2,556.3 \pm 32.7^{\mathrm{h}}$ & $6.4 \pm 0.1^{\mathrm{a}}$ & $935.8 \pm 14.6^{\mathrm{f}}$ \\
\hline 2 & $24.9 \pm 0.5^{\mathrm{d}}$ & $101.7 \pm 0.9^{\mathrm{b}}$ & ND & $229.6 \pm 4.0^{\mathrm{b}}$ & $\mathrm{ND}^{c}$ & $3,676.4 \pm 4.3^{\mathrm{g}}$ & $1.6 \pm 0.0^{\mathrm{b}}$ & $1,378.3 \pm 18.6^{\mathrm{e}}$ \\
\hline 3 & $30.6 \pm 0.7^{\mathrm{c}}$ & $\mathrm{ND}^{\mathrm{c}}$ & ND & $\mathrm{ND}^{\mathrm{c}}$ & $365.3 \pm 6.7^{\mathrm{b}}$ & $6,100.4 \pm 45.8^{\mathrm{f}}$ & $\mathrm{ND}^{c}$ & $2,302.1 \pm 51.2^{\mathrm{d}}$ \\
\hline 4 & $34.8 \pm 2.2^{\mathrm{b}}$ & $\mathrm{ND}^{\mathrm{c}}$ & ND & $\mathrm{ND}^{\mathrm{c}}$ & $421.9 \pm 18.7^{\mathrm{a}}$ & $7,459.9 \pm 51.9^{\mathrm{e}}$ & $\mathrm{ND}^{c}$ & $2,710.6 \pm 41.0^{c}$ \\
\hline 5 & $22.9 \pm 0.7^{\mathrm{d}}$ & $\mathrm{ND}^{\mathrm{c}}$ & ND & $\mathrm{ND}^{\mathrm{c}}$ & $343.3 \pm 3.8^{\mathrm{b}}$ & $7,842.2 \pm 161.3^{\mathrm{d}}$ & $\mathrm{ND}^{\mathrm{c}}$ & $2,832.4 \pm 81.5^{b}$ \\
\hline 6 & $35.2 \pm 1.6^{\mathrm{b}}$ & $\mathrm{ND}^{\mathrm{c}}$ & ND & $\mathrm{ND}^{\mathrm{c}}$ & $418.4 \pm 19.4^{\mathrm{a}}$ & $11,922.4 \pm 59.7^{\mathrm{b}}$ & $\mathrm{ND}^{\mathrm{c}}$ & $2,978.1 \pm 43.3^{\mathrm{a}}$ \\
\hline 7 & $35.6 \pm 1.6^{\mathrm{b}}$ & $\mathrm{ND}^{\mathrm{c}}$ & ND & $\mathrm{ND}^{\mathrm{c}}$ & $343.4 \pm 12.9^{\mathrm{b}}$ & $11,766.2 \pm 41.3^{\mathrm{c}}$ & $\mathrm{ND}^{\mathrm{c}}$ & $3,031.8 \pm 25.3^{\mathrm{a}}$ \\
\hline 8 & $38.3 \pm 1.9^{\mathrm{a}}$ & $\mathrm{ND}^{\mathrm{c}}$ & ND & $\mathrm{ND}^{\mathrm{c}}$ & $361.9 \pm 4.6^{\mathrm{b}}$ & $12,621.2 \pm 68.5^{\mathrm{a}}$ & $\mathrm{ND}^{c}$ & $2,800.9 \pm 54.1^{b}$ \\
\hline \multicolumn{9}{|c|}{ Storage period (days) and temperature $\left(25^{\circ} \mathrm{C}\right)$} \\
\hline 2 & $76.2 \pm 0.6$ & ND & ND & ND & ND & $4296.3 \pm 48.6$ & ND & $2913.3 \pm 6.9$ \\
\hline
\end{tabular}

${ }^{1}$ Each value is mean $\pm \mathrm{SD}(n=3)$.

${ }^{2}$ Means with the different superscript letters in the same column are significantly different $(p<0.05)$.

kimchi fermented at $25^{\circ} \mathrm{C}$ was found to be $2.03 \%$ and $2.22 \%$ at 0 and 2 days, respectively. From the previous literature, during the fermentation of kimchi with added abalone and kelp, the initial salinity was $1.37-1.67 \%$ and maintained at $2 \%$ because of the kimchi liquid and tissues of major and minor ingredients [28]. In another study, the kimchi made from summer Chinese cabbage of the alpine region, the salinity values of samples stored at $15^{\circ} \mathrm{C}$ and $5^{\circ} \mathrm{C}$ were $2.51-$ 2.58 and 2.50-2.58, respectively, whereas measuring by the Mohr method has given slightly lower values of 2.41-2.48 [2]. Thus, several studies proved that salinity does not inhibit the growth of microorganisms for the fermentation of kimchi.

3.5. Changes in Organic Acids Content. In this study, a total of eight organic acids including oxalic acid, citric acid, tartaric acid, malic acid, succinic acid, lactic acid, fumaric acid, and acetic acid were identified. The results of organic acids content of kimchi by various storage conditions are summarized in Table 4 . The results showed that the kimchi stored at $25^{\circ} \mathrm{C}$ for 2 days contained only oxalic acid, lactic acid, and acetic acid with the content levels $(\mathrm{mg} / \mathrm{kg})$ of $76.2 \pm 0.6,4296.3 \pm 78.6$, and $2913.3 \pm 6.9$. As shown in Figure S1 (A) in Supplementary Material available online at https://doi.org/10.1155/2017/9562981, the kimchi stored at $4^{\circ} \mathrm{C}$ ripened for 8 weeks, malic acid exhibited the highest content during the early storage, and lactic acid exhibited the highest content at 8 th week. The kimchi stored at $10^{\circ} \mathrm{C}$ ripened for 8 weeks, lactic acid content was markedly high at the early storage until 8 weeks followed by acetic acid content (Figure S1 (B)). Previous study reported that citric acid and malic acid gradually decrease as ripening progressed whereas lactic acid and acetic acid rapidly increase. Lactic acid was confirmed to be the main organic acid at the last stage of ripening [29]. Other study on kimchi added with abalone and kelp reported that citric acid, malic acid, and succinic acid contents were high during the initial fermentation stage and then gradually decreased as fermentation progressed, with the lactic acid and acetic acid contents increasing on days 7 and 14 of fermentation, respectively [28]. Furthermore, another study revealed that, after ripening of kimchi for 8 weeks at $5^{\circ} \mathrm{C}$, the lactic acid which was low during the early storage exhibited a marked increase from day 13 of storage, whereas malic acid exhibited a decrease and the succinic acid, oxalic acid, and malonic acid contents did not change [30].

With regard to the present study, in case of kimchi stored at $4^{\circ} \mathrm{C}$, the malic acid content was gradually decreased upon ripening and lactic acid content, which was not detected during early storage, rapidly increased at 5 th week of storage. The kimchi stored at $10^{\circ} \mathrm{C}$, lactic acid content was the highest from the early storage and its rate of increase became higher with increasing storage time. Malic acid content was not detected up to 2 weeks in the kimchi stored at $10^{\circ} \mathrm{C}$ and $25^{\circ} \mathrm{C}$. Similarly, the malic acid content in kimchi stored at $4^{\circ} \mathrm{C}$ and $10^{\circ} \mathrm{C}$ rapidly decreased and was not detected at 6 th and 4 th 


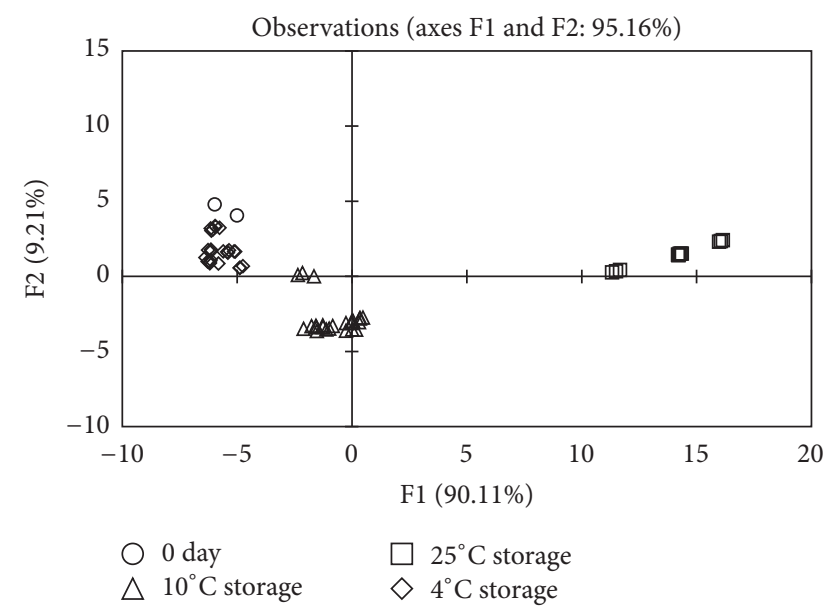

FIGURE 1: Distinction of kimchi samples at each storage temperature (0 days, $4^{\circ} \mathrm{C}, 10^{\circ} \mathrm{C}$, and $25^{\circ} \mathrm{C}$ ) by the organic acid content of each group using linear discriminant analysis (LDA).

week. The decrease in malic acid is reported to be caused by the conversion of malic acid to lactic acid and acetic acid by lactobacillus in kimchi [11]. The oxalic acid content did not change significantly with the storage period in kimchi stored at $4^{\circ} \mathrm{C}$ and $10^{\circ} \mathrm{C}$, and it was two times higher in kimchi stored at $25^{\circ} \mathrm{C}$. Fumaric acid had the lowest content $(1.6-11.1 \mathrm{mg} / \mathrm{kg})$.

When changes of the organic acid contents were compared, it was found that the changes in acidity are mainly dependent on lactic acid content. The studies showed that kimchi exhibit a $\mathrm{pH}$ of $4.2-4.6$ [8], acidity of $0.6-0.75 \%$ [16], and lactic acid content of $0.5-0.75 \%$ at the optimal fermentation time [31]. In the current study, kimchi stored at $4^{\circ} \mathrm{C}$ for 7 weeks and $10^{\circ} \mathrm{C}$ for 2 weeks was found to be the optimally fermented kimchi (Table 3). The lactic acid content in kimchi stored at $4^{\circ} \mathrm{C}$ for 7 weeks and that stored at $10^{\circ} \mathrm{C}$ for 2 weeks was $0.4 \%$ and $0.36 \%$, respectively, lower than those reported by Kim (1985) [31]. The lactic acid content in kimchi stored at $4^{\circ} \mathrm{C}$ for 8 weeks and that stored at $10^{\circ} \mathrm{C}$ for 3 weeks was found to be $0.5 \%$ and $0.6 \%$, respectively. Therefore, the optimal fermentation time for kimchi derived from lactic acid content appeared 1 week later than that derived from $\mathrm{pH}$ and acidity.

To distinguish kimchi at 0 days and those stored at 4,10 , and $25^{\circ} \mathrm{C}$, the organic acids content was used by performing linear discriminant analysis (LDA). As shown in Figure 1, the differentiation index was found to be $100 \%$ for kimchi at 0 day and that stored at $10^{\circ} \mathrm{C}$ and $25^{\circ} \mathrm{C}$, whereas it was $87.5 \%$ for the kimchi stored at $4^{\circ} \mathrm{C}$. From the results of LDA given in Figure 1, the kimchi samples could be significantly distinguished using all its data of organic acids content at each storage temperature with a separation index of $95.16 \%$.

\section{Conclusions}

The method of HPLC used for organic acids analysis was fully validated and the results were satisfied and in accordance with the criteria of Association of Official Analytical Chemists
(AOAC) in all cases. The lactic acid content increased according to the storage and was found to be a major component to affect the $\mathrm{pH}$ and acidity of the kimchi. The results of the organic acids analysis, the kimchi stored for eight weeks at $4^{\circ} \mathrm{C}$ and that for three weeks at $10^{\circ} \mathrm{C}$ were similar. However, acetic acid detected was relatively high at $10^{\circ} \mathrm{C}$ which might lead to a different flavour of kimchi. The $\mathrm{pH}$ was found to be decreased with storage time whereas acidity was increased.

\section{Additional Points}

Practical Applications. This study provides the information about the optimal fermentation conditions and the effect of $\mathrm{pH}$, acidity, salinity, and organic acids on the quality of kimchi so as to avoid spoilage of fermented kimchi. The findings of this study could be useful for the fermentation of better quality of kimchi.

\section{Competing Interests}

The authors declare no conflict of interests.

\section{Acknowledgments}

The authors acknowledge financial support from the World Institute of Kimchi, Gwangju, Republic of Korea, for this study.

\section{References}

[1] D. K. Kim, S. Y. Kim, J. K. Lee, and B. S. Noh, "Effect of xylose and xylitol on the organic acid fermentation of Kimchi," Korean Journal of Food Science and Technology, vol. 32, pp. 889-895, 2000.

[2] Y. S. Jeon, I. S. Kye, and H. S. Cheigh, "Changes of vitamin C and fermentation characteristics of kimchi on different cabbage variety and fermentation temperature," Journal of the Korean Society of Food Science and Nutrition, vol. 28, no. 4, pp. 773-779, 1999.

[3] H. J. Kim, H.-K. Shin, and E. J. Yang, "Production and fermentation characteristics of mukeunji with a mixed starter," Journal of the Korean Society of Food Science and Nutrition, vol. 42, no. 9, pp. 1467-1474, 2013.

[4] E. J. Cho, K. Y. Park, and S. H. Rhee, "Standardization of ingredient ratio of Chinese cabbage kimchi," Korean Journal of Food Science and Technology, vol. 29, pp. 1228-1235, 1997.

[5] N. J. Lee and J. K. Chun, "Studies on the kimchi pasteurization. Part 1. Method of kimchi pasteurization with Chinese cabbage kimchi and its effect on the storage," Journal of the Korean Society of Agricultural Chemistry and Biotechnology, vol. 24, no. 4, pp. 213-217, 1981.

[6] S. Y. Choi, M. K. Lee, K. S. Choi, Y. J. Koo, and W. S. Park, "Change of fermentation characteristics and sensory evaluation of kimchi on different storage temperature," Korean Journal of Food Science and Technology, vol. 30, pp. 644-649, 1998.

[7] I. H. Hyun, K. S. Kim, and N. H. Choung, "Effect of non-volatile organic acids in the kimchi by lactic acid bacteria," The Korean Journal of Food And Nutrition, vol. 3, pp. 141-148, 1990.

[8] K. H. Ku, K. K. Kang, and W. J. Kim, "Some quality changes during fermentation of kimchi," Korean Journal of Food Science and Technology, vol. 20, pp. 476-482, 1988. 
[9] H. O. Kim and H. S. Rhee, "Studies on the nonvolatile organic acids in kimchi fermented at different temperatures," Korean Journal of Food Science and Technology, vol. 7, pp. 74-81, 1975.

[10] J. Y. Ryu, H. S. Lee, and H. S. Rhee, "Changes of organic acids and volatile flavor compounds of kimchis fermented with different ingredients," Korean Journal of Food Science and Technology, vol. 16, pp. 169-174, 1984.

[11] Y. J. Moon, K. A. Baek, and C. K. Sung, "Characterization of biological chemistry from over ripened kimchi," The Korean Journal of Food And Nutrition, vol. 14, pp. 512-520, 2001.

[12] J. H. Kang, S. H. Kang, E. S. Ahn, M. J. Yoo, and H. J. Chung, "Effect of the combination of fermentation temperature and time on the properties of baechu kimchi," Journal of The Korean Society of Dietary Culture, vol. 19, pp. 30-42, 2004.

[13] K. H. Lee, H. Y. Cho, and Y. R. Pyun, "Kinetic modeling for the prediction of shelf-life of kimchi based on total acidity as a quality index," Korean Journal of Food Science and Technology, vol. 23, pp. 306-310, 1991.

[14] AOAC, Official Methods of Analysis, Method 33.7, Association of Official Analytical Chemists, Arlington, Va, USA, 16th edition, 1995.

[15] AOAC, Official Methods of Analysis, Method 420, Association of Official Analytical Chemists, Washington, DC, USA, 14th edition, 1984.

[16] K. O. Kim and W. H. Kim, "Change in properties of kimchi prepared with different kinds and levels of salted and fermented sea foods during fermentation," Korean Journal of Food Science and Technology, vol. 26, pp. 324-330, 1994.

[17] N. Khan, I. S. Jeong, I. M. Hwang et al., "Method validation for simultaneous determination of chromium, molybdenum and selenium in infant formulas by ICP-OES and ICP-MS," Food Chemistry, vol. 141, no. 4, pp. 3566-3570, 2013.

[18] L. H. Pacquette, A. Szabo, J. J. Thompson, and S. Baugh, "Application of inductively coupled plasma/mass spectrometry for the measurement of chromium, selenium, and molybdenum in infant formula and adult nutritional products: first action 2011.19," Journal of AOAC International, vol. 95, pp. 588-598, 2012.

[19] M. Thompson, S. L. R. Ellison, and R. Wood, "Laboratory validation of methods-harmonized guidelines," Pure and Applied Chemistry, vol. 74, pp. 835-855, 2002.

[20] M. Chudzinska and D. Baralkiewicz, "Application of ICPMS method of determination of 15 elements in honey with chemometric approach for the verification of their authenticity," Food and Chemical Toxicology, vol. 49, no. 11, pp. 2741-2749, 2011.

[21] R. I. Jennrich, Stepwise Discriminant Analysis, Statistical Methods for Digital Computers, Edited by K. Enslein, A. Ralston, H. S. Wilf, John Wiley \& Sons, New York, NY, USA, 1977.

[22] H.-A. Lee, Y.-O. Song, M.-S. Jang, and J.-S. Han, "Effect of Ecklonia cava on the quality Kimchi during fermentation," Journal of the Korean Society of Food Science and Nutrition, vol. 42, no. 1, pp. 83-88, 2013.

[23] Y. S. Bang, Y. G. Joh, and S. I. Moon, "The change of free amino acid composition during radish kimchi fermentation," Journal of the Korean Home Economics Association, vol. 23, pp. 55-60, 1985.

[24] I. S. Lee, W. S. Park, Y. J. Koo, and K. H. Kang, "Changes in some characteristics of brined Chinese cabbage of fall cultivars during storage," Korean Journal of Food Science and Technology, vol. 26, pp. 239-245, 1994.
[25] T. I. Mheen, T. W. Kwon, and C. H. Lee, “Traditional fermented food products in Korea," Korean Journal of Applied Microbiology and Biotechnology, vol. 9, pp. 253-261, 1981.

[26] M. J. Yoo, H. R. Kim, and H. J. Chung, "Change in physicochemical and microbiological properties in low-temperature and long-term fermented kimchi during fermentation," Journal of The Korean Society of Dietary Culture, vol. 16, pp. 431-441, 2001.

[27] T. I. Mheen and T. W. Kwon, "Effect of temperature and salt concentration on kimchi fermentation," Korean Journal of Food Science and Technology, vol. 16, pp. 443-450, 1984.

[28] J.-H. Lim, S.-S. Park, J.-W. Jeong, K.-J. Park, K.-H. Seo, and J.-M. Sung, "Quality characteristics of kimchi fermented with abalone or sea tangle extracts," Journal of the Korean Society of Food Science and Nutrition, vol. 42, no. 3, pp. 450-456, 2013.

[29] S. T. Jeong, J. G. Kim, and E. J. Kang, "Quality characteristics of winter Chinese cabbage and changes of quality during the kimchi fermentation," Journal of the Korean Society of PostHarvest Science \& Technology of Agricultural Products, vol. 6, pp. 178-183, 1999.

[30] W. D. Hawer, J. H. Ha, H. M. Seong, Y. J. Nam, and D. W. Shin, "Changes in the taste and flavor compounds of kimchi during fermentation," Korean Journal of Food Science and Technology, vol. 20, pp. 511-517, 1988.

[31] S. D. Kim, "Effect of pH adjuster on the fermentation of kimchi," Journal of the Korean Society of Food Science and Nutrition, vol. 14, pp. 259-264, 1985. 

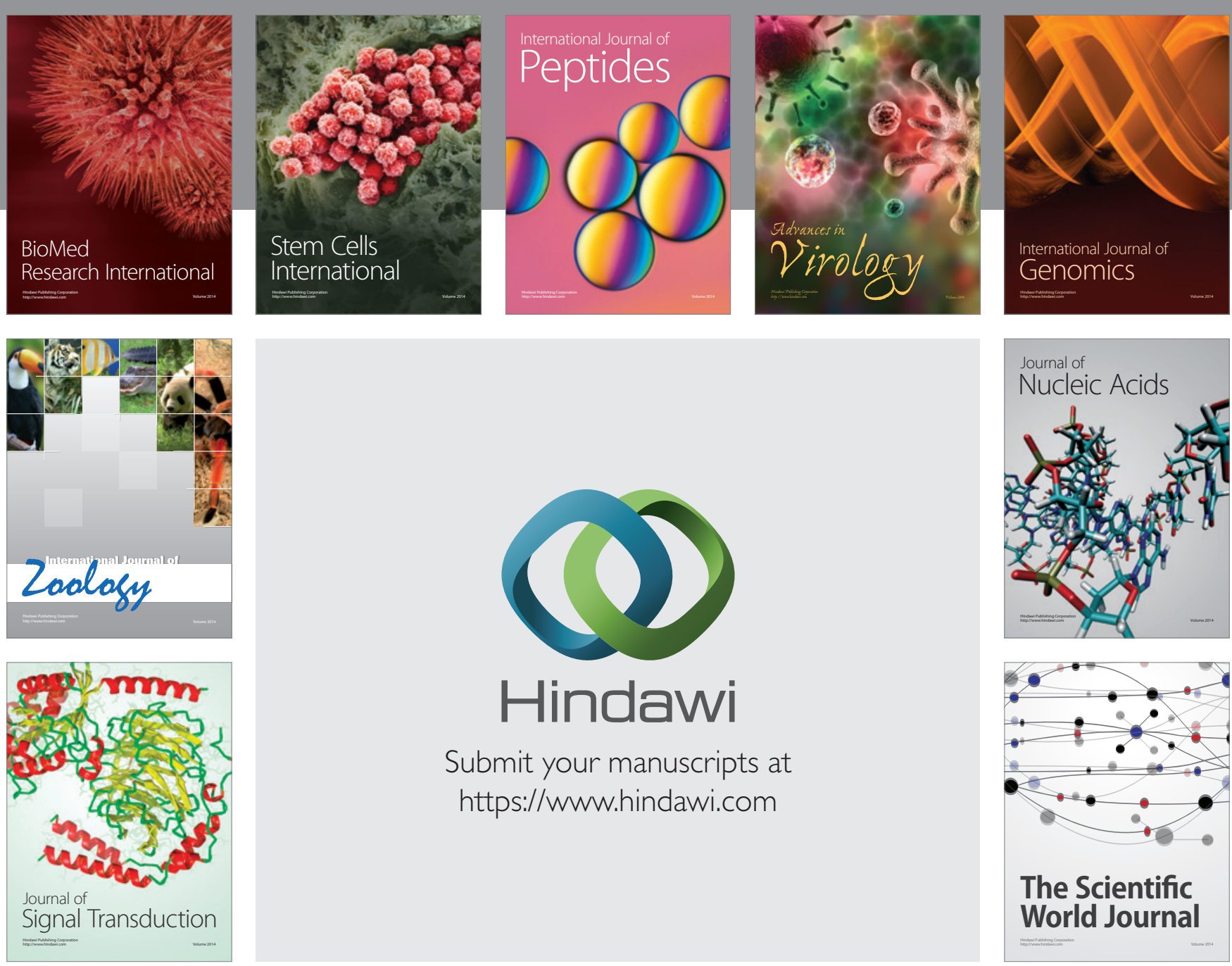

Submit your manuscripts at

https://www.hindawi.com
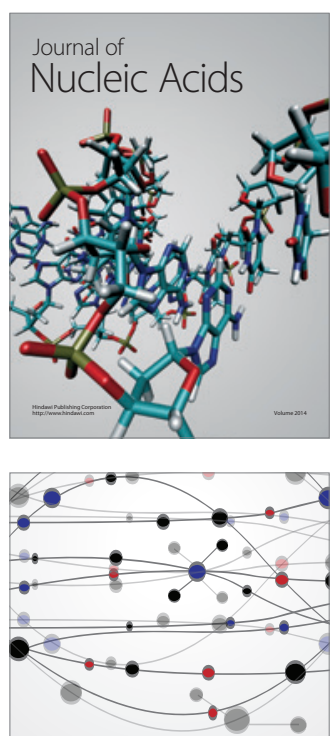

The Scientific World Journal
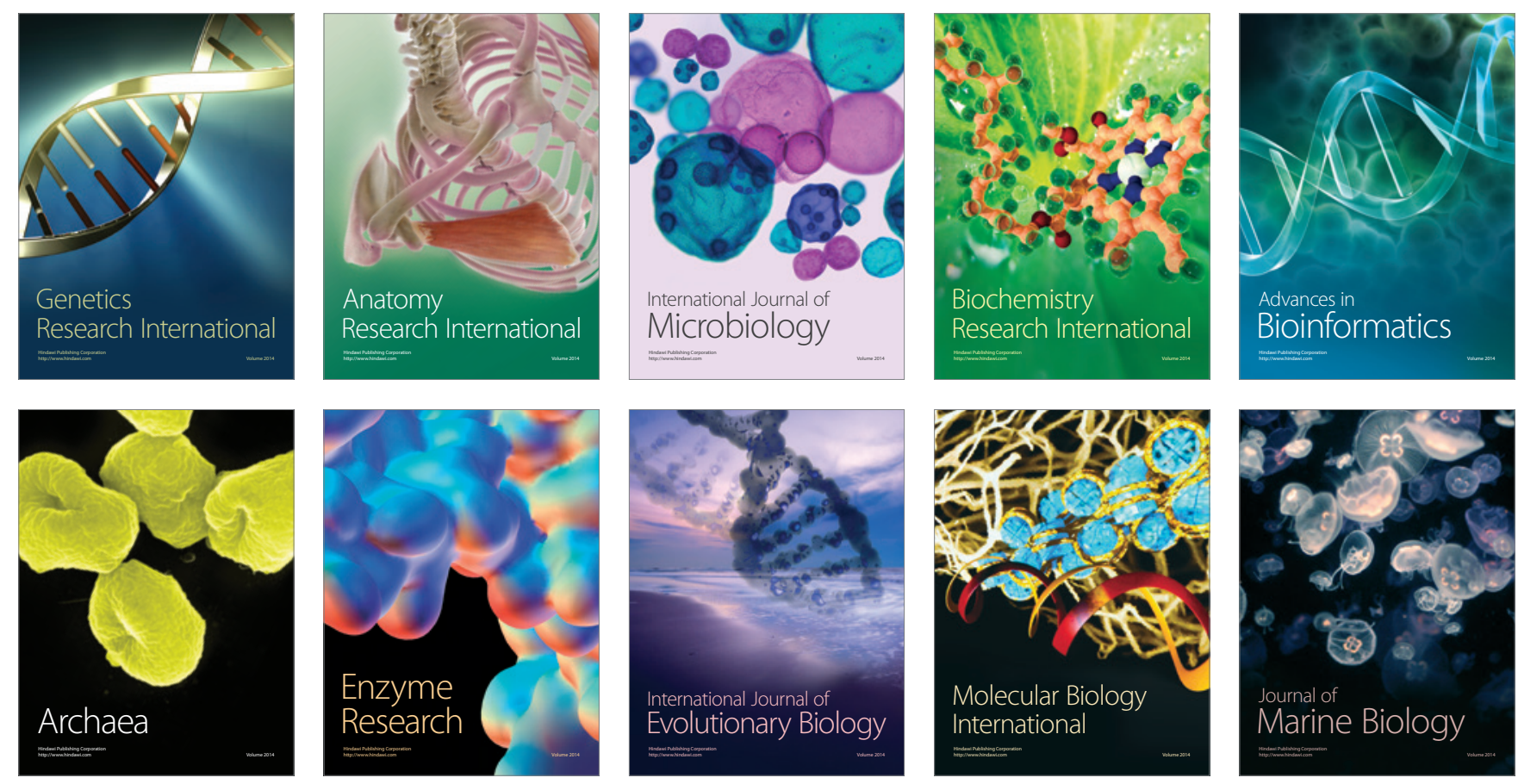